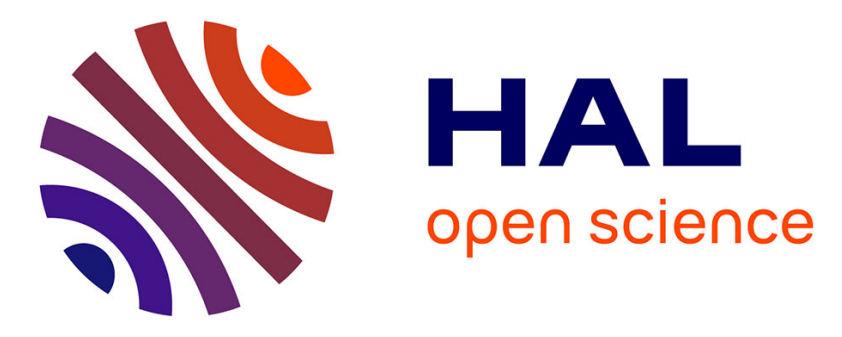

\title{
The evolution of a key character, or how to evolve a slipper lobster
}

Joachim T. Haug, Denis Audo, Sylvain Charbonnier, Ferran Palero, Gilles Petit, Pierre Abi Saad, Carolin Haug

\section{- To cite this version:}

Joachim T. Haug, Denis Audo, Sylvain Charbonnier, Ferran Palero, Gilles Petit, et al.. The evolution of a key character, or how to evolve a slipper lobster. Arthropod Structure and Development, 2016, 45 (2), pp.97-107. 10.1016/j.asd.2015.08.003 . hal-01191654

\section{HAL Id: hal-01191654 https://hal-univ-rennes1.archives-ouvertes.fr/hal-01191654}

Submitted on 1 Dec 2015

HAL is a multi-disciplinary open access archive for the deposit and dissemination of scientific research documents, whether they are published or not. The documents may come from teaching and research institutions in France or abroad, or from public or private research centers.
L'archive ouverte pluridisciplinaire HAL, est destinée au dépôt et à la diffusion de documents scientifiques de niveau recherche, publiés ou non, émanant des établissements d'enseignement et de recherche français ou étrangers, des laboratoires publics ou privés. 


\section{The evolution of a key character, or how to evolve a slipper lobster}

Joachim T. Haug ${ }^{\mathrm{a},}$, , Denis Audo ${ }^{\mathrm{b}}$, Sylvain Charbonnier ${ }^{\mathrm{c}}$, Ferran Palero ${ }^{\mathrm{d}}$, Gilles Petit ${ }^{\mathrm{c}}$, Pierre Abi Saad $^{\mathrm{e}}$ and Carolin Haug ${ }^{\mathrm{a}}$

${ }^{\text {a }}$ LMU Munich

Department of Biology II and GeoBio-Center

Großhaderner Str. 2, 82152 Martinsried-Planegg, Germany.

joachim.haug@palaeo-evo-devo.info

carolin.haug@palaeo-evo-devo.info

${ }^{\mathrm{b}}$ Université de Rennes, EA 7316

263 Avenue du General Leclerc CS 74205, 35042 Rennes Cedex, France.

denis.audo@univ-rennes1.fr

${ }^{\mathrm{c}}$ Muséum national d'Histoire naturelle, Paris

UMR 7207 CR2P, CNRS-MNHN-UPMC

case postale 38, 57 rue Cuvier, 75231 Paris Cedex 05, France.

scharbonnier@mnhn.fr

gilles.petit@upmc.fr

${ }^{\mathrm{d}}$ Institut Sophia Agrobiotech (INRA)

400 route des Chappes, BP 167, 06903 Sophia Antipolis Cedex, France.

Ferran.Palero@sophia.inra.fr

${ }^{\mathrm{e}}$ Memory of time, Citadel area, Byblos, Lebanon 


\begin{abstract}
A new fossil lobster from the Cretaceous of Lebanon, Charbelicaris maronites gen. et sp. nov., is presented here, while the former species 'Cancrinos' libanensis is re-described as Paracancrinos libanensis comb. nov. P. libanensis is shown to be closer related to the contemporary slipper lobsters than to Cancrinos claviger (lithographic limestones, Jurassic, southern Germany). A finelygraded evolutionary scenario for the slipper-lobster morphotype is reconstructed based on these fossil species and extant forms. The evolutionary changes that gave rise to the current plate-like antennae of Scyllaridae, a key apomorphy of this group, are traced back through time. The antenna of what is considered the oldest slipper lobster became petaloid and consisted of about 20 fully articulated elements. For this group the name Scyllarida sensu lato tax. nov. is introduced. In a next evolutionary step, the proximal articles became conjoined and a lateral extension appeared on peduncle element 3 . The entire distal petaloid region is conjoined already at the node of Verscyllarida tax. nov. In modern slipper lobsters, Neoscyllarida tax nov., the distal region is no longer petaloid in shape but asymmetrical. The study also emphasizes that exceptionally preserved fossils need to be documented with optimal documentation techniques to obtain all available information.
\end{abstract}

\title{
Highlights
}

- We describe new fossil, 90 million years old slipper lobsters (in the wide sense).

- These new fossils narrow the gap in the character evolution of slipper lobsters.

- Specifically the evolution of the special antenna can be reconstructed step by step.

Keywords: Achelata; character evolution; Scyllarida s. str.; Verscyllarida; autofluorescence imaging; limestones 


\section{Introduction}

Distinct morphotypes have been discussed repeatedly within Decapoda in recent years, with a focus on evolutionary scenarios leading to these morphotypes. A particularly 'hot' topic has been the process of 'carcinisation', or the evolution of the 'crab' morphotype respectively the evolution of a crab-like habitus (e.g. McLaughlin and Lemaitre 1997; McLaughlin et al. 2004; Hiller et al. 2010; Tsang et al. 2011; Scholtz 2014). In evolutionary terms, any form of crab has evolved from an ancestral macruran or "lobster" morphotype. An interesting and much less studied case of departure from the simple "lobster" morphotype are the slipper lobsters, or scyllarids, easily differentiable from other decapod lobsters due to their unique morphology (e.g. Jones 1990). The group Scyllaridae forms a sharply characterised natural group, distinguished by wide and flat segments of the peduncle of the antennae (a2, second antennae) and by having the antennal flagellum transformed to a single broad and flat element without a trace of articulation. Scyllarid lobsters can be considered to represent a distinct 'morphotype' (note that the term used here is more or less equivalent what other authors term 'bauplan'; yet this has a quite difficult meaning in German), and this is especially apparent when comparing them to their closest relatives, the palinurid lobsters (e.g. Palero et al. 2009; Bracken-Grissom et al. 2014). Scyllaridae and Palinuridae form together Achelata (Scholtz and Richter 1995), characterized by the lack of true claws (i.e. no index or fixed finger is opposed to the dactylus, or it is very short) and the presence of a phyllosoma larva. Contrary to the most familiar lobster types, slipper lobsters are dorsoventrally flattened, so that their cephalo-thoracic dorsal shield (also called carapace) is sometimes very wide, often square-shaped (in dorsal view) or even anteriorly widened. The dorsoventrally flattened body and, more importantly, the distinctive antennae of scyllarid lobsters must have evolved in their own evolutionary lineage.

The structure of the highly specialized, shovel-like antennae of scyllarid lobsters is remarkable. According to Holthuis (1991) the basal element of the antennal peduncle is conjoined with the carapace; so it is only visible ventrally (treated as peduncle element 1 in the following). The second and third element are conjoined to a single element which is short and broad and may bear teeth on the anterior margin (treated as peduncle element 2). In most scyllarids this element is free. In Scyllarus, however, it is immovably connected with the antennular somite and the carapace, thereby forming an integral part of the orbit (Holthuis 1985). The fourth element is large, broad and flat; it usually bears teeth on its margins (treated as peduncle element 3 ). The fifth segment is narrow and small; it may bear teeth on the inner margin (treated as peduncle element 4). The last element of the antenna, which represents the flagellum, is very broad and flat, sometimes with teeth on the margin. This element, together with the fourth one, is what makes the antenna into a broad, 
shovel-like organ for which the vernacular names 'shovel nose shrimp' and 'bulldozer lobster' are given to species of scyllarids. By providing "intermediate forms", fossils have the potential to provide further insights in the origin of key synapomorphies, such as the scyllarid antenna. Phylogenetically expressed, early fossil representatives of a group often have only part of the apomorphies of the modern group, while still lacking others. In this way the sequence in which the specializations of a morphotype evolved can be broken down into several, more gradual evolutionary transformations (examples in Senter 2010; Haug et al. 2010).

The Upper Jurassic Solnhofen lithographic limestones (ca. 150 million years old, southern Germany) yielded the fossils of Archaeopteryx lithographica, an important early representative of birds still lacking some autapomorphies of the modern representatives, thus representing an example of a fossil providing an "evolutionary step in between". But the Solnhofen lithographic limestones also yielded an important early representative of slipper lobsters, which provides insight into the evolution of their specific morphotype. Cancrinos claviger resembles spiny lobsters in general habitus. Yet, its antennae have a rather stout petaloid shape and comprise only about 20 elements. Förster $(1973,1984,1985)$ therefore suggested that C. claviger represents an evolutionary step towards slipper lobsters. Haug et al. (2009a) could add additional insights into the evolutionary transition from the morphotype of spiny lobsters to $C$. claviger. Early juveniles of $C$. claviger still possess an elongate multi-annulated antenna and develop the petaloid shape gradually, by widening of the proximal elements and finally loss of the distal feeler-like part. Yet, the further evolutionary transition from the morphology of $C$. claviger, which mainly appears like a highly specialized spiny lobster, to the very distinct morphotype of slipper lobsters is still unclear.

We present new fossils from the Cretaceous of Lebanon that further close the gap of knowledge about the evolution of the morphotype of slipper lobsters. Based on these we reconstruct a possible scenario for the evolution of the slipper lobster morphotype.

\section{Material and methods}

\subsection{Material}

Most material is part of the palaeontological collections of the Muséum national d'Histoire naturelle, Paris, France (acronym: MNHN.F). The material was collected during a field campaign in 2011 (SC, DA, GP) in the Late Cretaceous Lagerstätten of Lebanon: Hadjoula and Hakel (Cenomanian, $\sim 95 \mathrm{Ma}$ ) and Sahel Alma (Santonian, $~ 85 \mathrm{Ma}$ ). Comparative specimens are housed in the palaeontological collections of the Museo civico di Storia naturale di Milano (acronym: MSNM). 
Lebanese Lagerstätten are well-known for their exquisitely preserved crustacean faunas. For details see: Brocchi 1875; Fraas 1878; Dames 1886; Glaessner 1945; Roger 1946; Garassino 1994, 2001; Larghi 2004; Garassino and Schweigert 2006; Ahyong et al. 2007; Feldmann 2009; Garassino et al. 2009; Feldmann and Charbonnier 2011; Pasini and Garassino 2011; Petit and Charbonnier 2012; Charbonnier et al. 2013; Haug et al. 2013. For geological setting, see Ferry et al. (2007) and Audo and Charbonnier (2012, 2013).

\subsection{Methods}

Specimens from Paris have been documented using the macro-fluorescence settings described by Haug et al. (2011a) and Haug and Haug (2011). In most cases grey scale images of fluorescence images were produced by deleting blue and green channel, desaturating the red channel and optimizing the histogram. In some cases a better contrast was achieved by the following procedure: saturation dialog was opened, brightness of 'blue' and 'cyan' was set to '0', the brightness of 'red' was set to '100'. The resulting image was desaturated, and the histogram was optimized. Some specimens were additionally documented as stereo images (see e.g. Haug et al. 2011b, 2012a). Stereo images had their brightness values inverted to enhance the contrast.

Specimens from Milano were imaged by a Nikon D700 digital camera equipped with a Sigma $105 \mathrm{~mm}$ macro-lens with or without extension tube. Fossils display autofluorescence under UV light (yellow) and green light (orange) (see Haug et al. 2009b). Macrofluorescence was therefore used to document their anatomy. Under cross-polarized light, spotlights and lens were equipped with linear polarizing filters arranged so that reflexions would be minimal. Under UV light, a portable UV light set to short wave UV (emission peak around $254 \mathrm{~nm}$ ) was used. Under green-orange fluorescence, spotlights were equipped with medium blue-green gelatine filter and camera macro-lens equipped with a red filter to cancel all light but orange fluorescence. All raw image files were processed in Adobe Camera Raw and Gimp to adjust white balance and levels.

\subsection{Description}

The description of the here presented specimens is provided as a descriptive matrix (Haug et al. $2012 b$ ). This is thought to allow the taxonomically interested reader to access all necessary information, without centering this paper on this aspect.

\subsection{Phylogenetic reconstruction}

The present study focuses on the evolution of a series of characters of the antenna which resolve without character conflict. For this reason, there was no need to use computer-based phylogenetic analyses. This situation also has the advantage to avoid "hiding" apomorphies in a large matrix 
where they would be mixed with various characters, and the contribution of each character might end up difficult to assess. We will therefore concentrate on discussing the primary homology assumptions and the resulting evolutionary scenario.

\title{
3. Taxonomy
}

\author{
Eucrustacea sensu Walossek, 1993 \\ Malacostraca Latreille, 1802 \\ Decapoda Latreille, 1802 \\ Reptantia Boas, 1880 \\ Achelata Scholtz and Richter, 1995 \\ Scyllarida sensu lato tax. nov. (see discussion) \\ Scyllarida sensu stricto tax. nov. (see discussion)
}

Paracancrinos gen. nov.

Derivatio nominis: "Cancrinos" for the similarities to this genus and "para" for stressing the difference to it.

Type species: Cancrinos libanensis Garassino and Schweigert, 2006, by monotypy.

Diagnosis: as for the species.

Remarks: The erection of this new genus becomes necessary as the species libanensis Garassino and Schweigert, 2006 was originally ascribed to the genus Cancrinos Münster, 1839. Yet, it shares one key character with other scyllarids that Cancrinos claviger is lacking: the non-separation of the proximal elements of the petaloid region of the antenna (see below). In consequence Cancrinos would become paraphyletic. Therefore, the species C. libanensis Garassino and Schweigert, 2006 has to be excluded and (following Linnean taxonomy) demands for the erection of its own genus.

Paracancrinos libanensis (Garassino and Schweigert, 2006) comb. nov.

Type material: holotype MSNM i26597 (Figs. 1, 2A-C), paratype MSNM i26593 (Figs. 1, 2D, E). Additional material: two specimens MNHN.F.A48952 (Figs. 1, 3A, 4A), A48973 (Fig. 5A, B). Amended diagnosis: Small-sized achelatan with a carapace of rectangular shape (dorsal view); strong and stout petaloid flagellum of antenna; distally with fully articulated elements, proximal elements conjoined. 
Description: Full description is provided as descriptive matrix in supplement.

Remarks: Our description differs in certain aspects from the original one. This is most likely facilitated by the additional material, but also by the application of macro-fluorescence imaging. Most important, the petaloid part of the antenna has fully jointed articles only distally, further proximally these are conjoined (Figs. 3B, 5D, E). Garassino and Schweigert (2006) described the species as lacking a rostrum. Our new material as well as re-investigation of the type material indicates the presence of a short rostrum (Fig. 5B). Furthermore the authors described the uropod exopod as lacking a diaeresis (subdivided by a joint). The morphology of the typical achelatan uropod makes this interpretation difficult, as the distal part of the uropod exopod is soft, while the proximal part is strongly sclerotized (Figs. 2E, 3A, C, 5F). The decision comes down to the question whether this situation is homologous to a diaeresis or not. We leave this question open, but want to point to this difficulty. A further difference to the original description is the relation of lengths (carapace length vs. pleon length). Garassino and Schweigert (2006) stated that the "abdomen" (pleon) is as long as the carapace. Yet as the anterior rim of the carapace is difficult to assess (due to the strong antennal peduncles) this was most likely a measuring error. The length of the carapace equals about the length of four pleomeres. Furthermore, fluorescence light microscopy revealed some aspects of the tail fan that differ from the original description. The rim of the hard part of the telson is straight, not convex (Fig. 2E). Carinae on telson and uropod exopod are not apparent; possibly these are compressions of uropod endopod and exopod rims. Last point, what Garassino and Schweigert (2006) described as "fringed" might have referred to the stiffeners of the softer part of endopod and exopod. A further point is the length and robustness of the thoracopods 4-8 (=pereiopods 1 to 5 in decapod crustaceans). We find these difficult to assess due to preservation, and neither support nor disprove whether thoracopod 4 (pereiopod 1) is shorter and stouter than the others (Fig. 4B).

Verscyllarida tax. nov. (see discussion)

\section{Charbelicaris gen. nov.}

\section{Type species: Charbelicaris maronites}

Etymology: in honor of Youssef Antoun Makhlouf also known as Saint Charbel, hermit of Mount Lebanon, near Hadjoula.

Diagnosis: as for the species 
Etymology: from the Maronites, an ethnoreligious group in Levant who established the Maronite Church from Lebanon; used as a noun in apposition.

Type material: holotype MNHN.F.A48955 (Fig. 6A-C), paratype MNHN.F.A48984 (Fig. 6D-G). Type locality: Hadjoula Lagerstätte, Lebanon (Late Cretaceous, Cenomanian).

Diagnosis: Small-sized achelatan with a carapace of rectangular shape (dorsal view); strong and stout petaloid flagellum of antenna; all elements conjoined. Third article of antenna laterally extending into leaf-shaped structure.

Description: Full description is provided as descriptive matrix in supplement.

Remarks: Specimens like the here described ones appear to have been treated among collectors and sellers as Palibacus praecursor (Dames, 1886). Yet, the material of $\mathrm{Pb}$. praecursor described by Förster (1984) has a strongly more derived antenna and carapace morphology (work in preparation). The material of Förster appears to be conspecific with the incomplete type described by Dames (1886). Hence, the here described specimens represent a yet unnamed species, now called Charbelicaris maronites.

\section{Discussion}

\subsection{Preservation and degree of detail}

The preservation of the here described specimens is exceptional. It is not restricted to sclerotized hard parts. Also soft details like those of the distal parts of the tail fan are perfectly preserved. Yet, comparing our observations to earlier ones indicates that even exceptionally preserved details demand for the right documentation method. Looking at the original image of the antenna of the types of Paracancrinos libanensis (Garassino and Schweigert 2006, their fig. 6) one gets the impression of a complete subdivision, including that of the proximal articles. This impression is most likely caused by shadows. These are caused by slight elevations that might indicate a former or future (see below) subdivision. Only the fluorescence images reveal the differences of the articulated situation of the distal articles and the conjoined condition of the proximal ones. Hence, fluorescence imaging agin proves to be valuable in revealing important details (for further discussions, see for example Haug et al. 2009b, 2011a; Kerp and Bomfleur 2011, and references therein).

\subsection{Ascription to Paracancrinos libanensis}


The newly described specimens differ in some aspects of their morphology from the two type specimens of Paracancrinos libanensis. We interpret these minor differences as caused by ontogenetic variance. The two new specimens are slightly smaller than the two type specimens. Comparing their size indicates that the two new specimens are probably one instar younger than the type specimens.

The new specimens of Paracancrinos libanensis possess a short flagellate part distally on the petaloid region of the antenna (Fig. 3B) which appears to be absent in the type specimens (Fig. 2). In the ontogeny of Cancrinos claviger a long flagellate antenna at first becomes widened proximally during late juvenile development, hence roughly resembling the condition in the specimens at hand. The distal flagellum finally gets lost in C. claviger, retaining only the proximal (then petaloid) part (Haug et al. 2009a). Hence, this demonstrates that it is likely that the same type of ontogenetic loss is also present in the here described case. This interpretation provides a possible explanation for the fact that the antennae in the type specimens have fewer articles.

As all specimens come from the same locality, we cannot argue with geographic or time differences for basing a new species on the two new specimens. An interpretation as an ontogenetic difference seems more parsimonious than erecting a new species based on these differences.

\subsection{Evolutionary scenario: interpreting antennal morphologies}

The antennal morphologies of the species described here are significant for understanding the evolution of the peculiar scyllarid antenna (Fig. 7). Cancrinos claviger possesses a distal petaloidshaped region of the antenna, comprising about 20 articles of the flagellum. The peduncle elements 3 and 4 are symmetrically shaped. This condition is still very similar to that found in Palinurida (interpreted as retained plesiomorphies), besides the short and petaloid shape of the distal part.

A relatively similar condition is seen in Paracancrinos libanensis. Also the newly found short rostrum could represent a rather plesiomorphic character as it resembles that seen, e.g., in species of the palinurid group Palinurellus. Yet, certain aspects of the antenna of P. libanensis appear further derived than in C. claviger. The petaloid region resembles that of C. claviger; it most likely also has about or slightly less than 20 articles. Yet, unlike in C. claviger only the distal articles appear to be fully separated from each other. In the proximal region single articles are recognizable by indentations along the sides, yet, they appear to be continuous along the main surface (Fig. 3B). We interpret this partially conjoined condition of articles as leading to a fully conjoined condition (see further below). Furthermore, peduncle elements 3 and 4 are asymmetrical; they are slightly drawn out laterally (Figs. 4B, 5B).

In Charbelicaris maronites the condition is further derived. The antenna is already clearly recognizable as a "typical" scyllarid antenna. Only a single element forms the distal petaloid part, 
no subdivisions are apparent (Fig. 6B, E, F). Yet, the general shape and the indentations along the rim strongly resemble the condition seen in P. libanensis. We therefore see this as a support of the assumption that the distal petaloid parts of $C$. claviger and P. libanensis are homologous to the petaloid region in Ch. maronites and modern scyllarids, and that the single petaloid structure is a product of fusion, or better non-separation of several elements. The indentations are consequently interpreted as an evolutionary "left-over" of this subdivision. Spines along the margin most likely evolved within modern scyllarids and are likely not homologous to these indents. The lateral edge of peduncle element 3 is drawn out into a petaloid extension with few teeth (Fig. 6E, F). Also this lateral extension is interpreted to be homologous to the lateral extension seen in P. libanensis (Fig. 3B).

In modern scyllarids, the antennal morphology is further derived. The distal part is, in most modern species, no longer symmetrical: this is most likely a ground pattern feature for the group (autapomorphy). The distal tip appears to point further laterally in modern scyllarids, which means that the median edge appears longer than the lateral edge. Furthermore, the lateral extension is in most species (and probably in the ground pattern) further elongated than in Ch. maronites.

\subsection{New systematics}

Haug et al. (2009a) suggested the name Scyllaridae sensu lato for the group comprising Cancrinos and modern slipper lobsters, which were suggested to be named Scyllaridae sensu stricto. This was intended to represent a strict phylogenetic naming. Yet, Karasawa et al. (2013) rejected these suggested group names, re-establishing a superfluous category (“empty bracket”), Cancrinidae, obviously mistaking the strict phylogenetic terms of Haug et al. (2009a) for taxonomic ones. To overcome this misunderstanding, we suggest here new terms for the different monophyletic groups in the evolutionary lineage towards modern slipper lobsters, emphasizing their phylogenetic meaning. Following Scholtz and Richter (1995), any endings related to specific ranks (e.g. -idae) are transformed to a neutral ending (-a).

Scyllarida sensu lato tax. nov. is autapomorphically characterized by the petaloid shape of the distal part of the antenna in the adult stage, which consists of about 20 well-separated elements. The monophyletic group comprises Cancrinos claviger and Scyllarida sensu stricto tax. nov. This characterization of Scyllarida sensu lato causes the difficulty that there is currently no character "left" for characterizing (diagnosing) a monophyletic group Cancrinos, or the species C. claviger. This is due to the relatively high resolution of the here discussed phylogeny.

Scyllarida sensu stricto tax. nov. is autapomorphically characterized by the partially conjoined condition of the proximal flagellar antennal articles. The known representatives 
additionally are characterized by the lateral extension of antennal peduncle element 3 . The monophyletic group comprises Paracancrinos libanensis and Verscyllarida tax. nov.

Verscyllarida tax. nov. is autapomorphically characterized by the fully conjoined condition of the distal antennal articles. All known representatives additionally show the further lateral extension of the third peduncle element of the antenna. The monophyletic group comprises $C h$. maronites and Neoscyllarida tax. nov.

Neoscyllarida tax. nov. is characterized by a shape change of the distal antennal region. It is no longer petaloid but more rounded, most likely by allometric growth of the original inner edge. Additionally, the lateral extensions of peduncle element 3 are more drawn out. Neoscyllarida comprises all modern representatives (= crown-group Scyllaridae).

\section{Conclusions and outlook}

The here presented case supports that important evolutionary novelties in scyllarids occurred during the Jurassic and Cretaceous (Förster 1973, 1984). Due to the exceptional preservation of several Lagerstätten in the Jurassic and Cretaceous we have direct access to these evolutionary changes. In the days of evo-devo it is especially fortunate that such fossils, e.g. of achelate lobsters, even give insights into the ontogeny (Polz 1971, 1972, 1973, 1987, 1995, 1996; Tanaka et al. 2009; Haug et al. 2011c, 2015; Audo and Charbonnier 2012) and thus facilitate a palaeo-evo-devo approach (Haug et al. 2009a, 2013; Haug and Haug 2013). More scyllarid and other achelatan fossils from the Mesozoic are currently worked up, and will likely provide new and additional insights.

To summarise, our new finds on Mesozoic fossils demonstrate:

- the importance of applying the right documentation method to exceptionally preserved fossils, - the step-wise evolution of the scyllarid morphotype, documented by these,

- that fossils are extremely important to resolve the stepwise evolution of a distinct modern morphotype.

\section{Acknowledgements}

This study was supported by numerous institutions and persons, which are all heartily thanked for. We thank Jonas Keiler, Rostock, and an anonymous reviewer for their comments on the manuscript. The visit of JTH to the MNHN was kindly funded by a grant from the European Commission's (FP6) Integrated Infrastructure Initiative programme SYNTHESYS FR-TAF-2590. CH has been 
supported by the German Academic Exchange Service (DAAD) with a return fellowship. JTH has been kindly funded by the Alexander von Humboldt Foundation with a Feodor Lynen return fellowship. This study is part of the project 'Palaeo-Evo-Devo of Malacostraca' of JTH kindly funded by the German Research Foundation (DFG) under Ha 6300/3-1. Field campaign in Lebanon was granted by the MNHN-ATM program Biodiversité actuelle et fossile. Crises, stress, restaurations et panchronisme : le message systématique. JTH and $\mathrm{CH}$ want to express their thanks to their former host Steffen Harzsch, Greifswald and to J. Matthias Starck, Munich for their support. We thank all people involved in providing open source, open access or low cost software, which also was used during this study, such as Open Office, GIMP, or Inkscape.

\section{References}

Ahyong, S.T., Garassino, A., Gironi, G., 2007. Archaeosculda phoenicia n. gen., n. sp. (Crustacea, Stomatopoda, Pseudosculdidae) from the Upper Cretaceous (Cenomanian) of Lebanon. Atti Soc. Ital. Sci. Nat. Mus. Civ. Stor. Nat. Milano 148(1), 3-15.

Audo, D., Charbonnier, S., 2012. New nisto of slipper lobster (Decapoda: Scyllaridae) from the Hadjoula Lagerstätte (Late Cretaceous, Lebanon). J. Crust. Biol. 32, 583-590.

Audo, D., Charbonnier, S., 2013. Late Cretaceous crest-bearing shrimps from the Sahel Alma Lagerstätte of Lebanon. Acta Palaeo. Pol. 58, 335-349.

Bracken-Grissom, H.D., Ahyong, S.T., Wilkinson, R., Yang, Z., Brienholt, J., Palero, F., Chan, T-Y., Bendall, M., Feldmann, R., Schweitzer, C., Chu, K.H., Felder, D.L., Robles, R., Kim, D., Tsang, M., Martin, J., Crandall, K.A., 2014. Emergence of the lobsters: phylogenetic relationships, morphological evolution and divergence time comparisons of a fossil rich group (Achelata, Astacidea, Glypheidea, Polychelida). Syst. Biol. 63, 457-479.

Brocchi, P., 1875. Note sur une nouvelle espèce de crustacé fossile (Penaeus libanensis). Bull. Soc. géol. France 3, 609-610.

Charbonnier, S., Garassino, A., Schweigert, G., Simpson, M., 2013. A worldwide review of fossil and extant glypheid and litogastrid lobsters (Crustacea, Decapoda, Glypheoidea). Mém. Mus. nation. Hist. nat. Paris 205, 1-304. 
Dames, W., 1886. Ueber einige Crustaceen aus dem Kreideablagerungen des Libanon. Z. dt. Geol. Ges. 38, 551-576.

Feldmann, R.M., 2009. A new cirolanid isopod (Crustacea) from the Cretaceous of Lebanon: dermoliths document the pre-molt condition. J. Crust. Biol. 29, 373-378.

Feldmann, R.M., Charbonnier, S., 2011. Ibacus cottreaui Roger, 1946, reassigned to the isopod genus Cirolana (Cymothoida: Cirolonidae). J. Crust. Biol. 31, 317-319.

Ferry, S., Merran, Y., Grosheny, D., Mroueh, M., 2007. Relations entre les marges septentrionale et méridionale de la Téthys au Crétacé. Carn. Géol. 6, 38-42.

Förster, R., 1973. Untersuchungen an oberjurassischen Palinuridae (Crustacea, Decapoda). Mitt. Bayer. Staatssamml. Paläo. histor. Geol. 13, 31-46.

Förster, R., 1984. Bärenkrebse aus dem Cenoman des Libanon und dem Eozän Italiens. Mitt. Bayer. Staatssamml. Paläo. histor. Geol. 24, 57-66.

Förster, R., 1985. Evolutionary trends and ecology of Mesozoic decapod crustaceans. Trans. R. Soc. Edinb. 76, 299-304.

Fraas, O., 1878. Geologisches aus dem Libanon. Jahresh. Vereins Naturk. Württ. 34, 257-391.

Garassino, A., 1994. The macruran decapod crustaceans of the Upper Cretaceous of Lebanon. Paleo. Lombar. Nuova ser. Soc. ital. Sci. nat. Mus. Civ. Stor. Nat. Milano 3, 3-27.

Garassino, A., 2001. New decapod crustaceans from the Cenomanian (Upper Cretaceous) of Lebanon. Atti Soc. Ital. Sci. Nat. Mus. Civ. Stor. Nat. Milano 141(2), 237-250.

Garassino, A., Schweigert, G., 2006. Cretasergestes sahelalmae n. gen., n. sp. (Crustacea, Decapoda, Sergestoidea) and Cancrinos libanensis n. sp. (Crustacea, Decapoda, Palinuroidea) from the Upper Cretaceous (Cenomanian) of Lebanon. Atti Soc. Ital. Sci. Nat. Mus. Civ. Stor. Nat. Milano 147, 69-78. 
Garassino, A., De Angeli, A., Pasini, G., 2009. A new hermit crab (Crustacea, Anomura, Paguroidea) from the Late Cretaceous (Cenomanian) of Lebanon. Atti Soc. Ital. Sci. Nat. Mus. Civ. Stor. Nat. Milano 150(2), 215-228.

Glaessner, M.F., 1945. Cretaceous Crustacea from Mount Lebanon, Syria. Ann. Mag. Nat. Hist. 11, 694-707.

Haug, C., Haug, J.T., Waloszek, D., Maas, A., Frattigiani, R., Liebau, S., 2009b. New methods to document fossils from lithographic limestones of southern Germany and Lebanon. Palaeo. Electron.12(3), art.6T, http://palaeo-electronica.org/2009_3/193/index.html

Haug, C., Mayer, G., Kutschera, V., Waloszek, D., Maas, A., Haug, J.T., 2011b. Imaging and documenting gammarideans. Int. J. Zool., art. 380829, DOI 10.1155/2011/380829

Haug, J.T., Haug, C., 2011. Fossilien unter langwelligem Licht: Grün-Orange-Fluoreszenz an makroskopischen Objekten. Archaeopteryx 29, 20-23.

Haug, J.T., Haug, C., Waloszek, D., Maas, A., Wulf, M., Schweigert, G., 2009a. Development in Mesozoic scyllarids and implications for the evolution of Achelata (Reptantia, Decapoda, Crustacea). Palaeodiversity 2, 97-110.

Haug, J.T., Haug, C., Maas, A., Kutschera, V., Waloszek, D., 2010. Evolution of mantis shrimps (Stomatopoda, Malacostraca) in the light of new Mesozoic fossils. BMC Evol. Biol. 10, art. 290, 17 pp.

Haug, J.T., Haug, C., Kutschera, V., Mayer, G., Maas, A., Liebau, S., Castellani, C., Wolfram, U., Clarkson, E.N.K., Waloszek, D., 2011a. Autofluorescence imaging, an excellent tool for comparative morphology. J. Microsc. 244, 259-272.

Haug, J.T., Haug, C., Waloszek, D., Schweigert, G., 2011c. The importance of lithographic limestones for revealing ontogenies in fossil crustaceans. Swiss J. Geosci. 104, Suppl. 1, S85-S98.

Haug, J.T., Briggs, D.E.G., Haug, C., 2012b. Morphology and function in the Cambrian Burgess Shale megacheiran arthropod Leanchoilia superlata and the application of a descriptive matrix. BMC Evol. Biol. 12, art. 162. 
Haug, J.T., Mayer, G., Haug, C., Briggs, D.E.G., 2012a. A Carboniferous non-onychophoran lobopodian reveals long-term survival of a Cambrian morphotype. Curr. Biol. 22, 1673-1675.

Haug, J.T., Audo, D., Charbonnier, S., Haug, C., 2013. Diversity of developmental patterns in achelate lobsters-today and in the Mesozoic. Dev. Genes. Evol. 223, 363-373.

Haug, J.T., Audo, D., Haug, C., Abi Saad, P., Petit, G., Charbonnier, S., 2015. Unique occurrence of polychelidan lobster larvae in the fossil record and its evolutionary implications. Gondwana Res. $28,869-874$.

Hiller, A., Viviana, C.A., Werding, B., 2010. Hypercarcinisation: an evolutionary novelty in the commensal porcellanid Allopetrolisthes spinifrons (Crustacea: Decapoda: Porcellanidae). Nauplius $18,95-102$.

Holthuis, L.B., 1985. A revision of the family Scyllaridae (Crustacea: Decapoda: Macrura). I. Subfamily Ibacinae. Zool. Verhand. 218, 1-130.

Holthuis, L.B., 1991. FAO Species Catalogue. Marine Lobsters of the World. An annotated and illustrated catalogue of species of interest to fisheries known to date. FAO Fisheries Synopsis 125(13). Rome, pp. 292.

Jones, C.M., 1990. Morphological characteristics of bay lobsters, Thenus, Leach species (Decapoda, Scyllaridae) from North-Eastern Australia. Crustaceana 59, 265-275.

Karasawa, H., Schweitzer, C.E., Feldmann, R.M., 2013. Phylogeny and systematics of extant and extinct lobsters. J. Crust. Biol. 33, 78-123.

Kerp, H., Bomfleur, B., 2011. Photography of plant fossils-New techniques, old tricks. Rev. Palaeobot. Palynol. 166, 117-151.

Larghi, C., 2004. Brachyuran decapod Crustacea from the Upper Cretaceous of Lebanon. J. Paleo. $78,528-541$. 
McLaughlin, P.A., Lemaitre, R., 1997. Carcinization in the Anomura - fact or fiction? I. Evidence from adult morphology. Contrib. Zool. 67, 79-123.

McLaughlin, P.A., Lemaitre, R., Tudge, C.C., 2004. Carcinization in the Anomura - fact or fiction. II. Evidence from larval, megalopal and early juvenile morphology. Contrib. Zool. 73, 165-205.

Palero, F., Crandall, K.A., Abelló, P., Macpherson, E., Pascual, M., 2009. Phylogenetic relationships between spiny, slipper and coral lobsters (Crustacea, Decapoda, Achelata). Mol. Phylogen. Evol. 50, $152-162$.

Pasini, G., Garassino, A., 2011. First direct predatory evidence of an eel-like fish on Pseudosculda cfr. P. laevis (Crustacea, Stomatopoda, Unipeltata) from the Late Cretaceous (Cenomanian) of Lebanon. Atti Soc. Ital. Sci. Nat. Mus. Civ. Stor. Nat. Milano 152(1), 69-78.

Petit, G., Charbonnier, S., 2012. Fossil sponge gemmules, epibionts of Carpopenaeus garassinoi $\mathrm{n}$. sp. (Crustacea, Decapoda) from the Sahel Alma Lagerstätte (Late Cretaceous, Lebanon). Geodiversitas 34, 359-372.

Polz, H., 1971. Eine weitere Phyllosoma-Larve aus den Solnhofener Plattenkalken. N. Jb. Geol. Paläontol. Mh. 1971, 474-488.

Polz, H., 1972. Entwicklungsstadien bei fossilen Phyllosomen (Form A) aus den Solnhofener Plattenkalken. N. Jb. Geol. Paläontol. Mh. 1972, 678-689.

Polz, H., 1973. Entwicklungsstadien bei fossilen Phyllosomen (Form B) aus den Solnhofener Plattenkalken. N. Jb. Geol. Paläontol. Mh. 1973, 284-296.

Polz, H., 1987. Zur Differenzierung der fossilen Phyllosomen (Crustacea, Decapoda) aus den Solnhofener Plattenkalken. Archaeopteryx 5, 23-32.

Polz, H., 1995. Ein außergewöhnliches Jugendstadium eines palinuriden Krebses aus den Solnhofener Plattenkalken. Archaeopteryx 13, 67-74.

Polz, H., 1996. Eine Form-C-Krebslarve mit erhaltenem Kopfschild (Crustacea, Decapoda, Palinuroidea) aus den Solnhofener Plattenkalken. Archaeopteryx 14, 43-50. 
Roger, J., 1946. Invertébrés des couches à poissons du Crétacé supérieur du Liban. Mém. Soc. géol. France (Nouv. Sér.) 51, 1-92.

Scholtz, G., 2014. Evolution of crabs - history and deconstruction of a prime example of convergence. Contrib. Zool. 83, 87-105.

Scholtz, G., Richter, S., 1995. Phylogenetic systematics of the reptantian Decapoda (Crustacea, Malacostraca). Zool. J. Linn. So. 113, 289-328.

Senter, P., 2010. Using creation science to demonstrate evolution: application of a method for visualizing gaps in the fossil record to a phylogenetic study of coelurosaurian dinosaurs. J. Evol. Biol. 23, 1732-1743.

Tanaka, G., Smith, R.J., Siveter, D.J., Parker, A.R., 2009. Three-dimensionally preserved decapod larval compound eyes from the Cretaceous Santana Formation of Brazil. Zool. Sci. 26, 846-850.

Tsang, L.M., Chan, T-Y., Ahyong, S.T., Chu, K.H., 2011. Hermit to king, or hermit to all: multiple transitions to crab-like forms from hermit crab ancestors. Syst. Biol. 60, 616-629. 


\section{Figure captions}

Fig. 1. Overview of the material of Paracancrinos libanensis (Garassino and Schweigert, 2006). New material, representing an earlier instar (MNHN.F.A48973, A48952). Type material, representing a later instar (holotype MSNM i26597, paratype MSNM i26593).

Fig. 2. Paracancrinos libanensis (Garassino and Schweigert, 2006), later instar, type material. A-C. Holotype MSNM i26597. A. Overview. B. Close-up of antenna. Arrows mark borders between articles. C. Close-up on antennula. D, E. Paratype MSNM i26593 48939. D. Overview. Arrows mark spines. E. Close-up on tail fan. Abbreviations: $1-14=$ antennal articles; an = antenna; at $=$ antennula; $\mathrm{ca}=$ carina; den $=$ distal uropod endopod; $\mathrm{dex}=$ distal uropod exopod; dte $=$ distal part of telson; $\mathrm{fl}=$ flagellum; le = lateral extension; on = optical notch; pex = proximal uropod exopod; $\mathrm{pl}$ $1-6=$ pleomeres; pte $=$ proximal region of telson; $r s=$ rostrum; te $=$ telson; $u r=$ uropod.

Fig. 3. Paracancrinos libanensis (Garassino and Schweigert, 2006), early instar MNHN.F.A48952. A. Overview. B. Close-up of petaloid region. Note the conjoined proximal region (1-4?), the distal articles (marked by arrows) and the distal short flagellum (“fl”). C. Close up of tail fan. Note the proximal hard region of telson (pte) and uropod rami (pen, pex) and the distal soft regions (dte, den, dex). Abbreviations: $1-15=$ antennal articles; an = antenna; at $=$ antennula; den $=$ distal uropod endopod; dex = distal uropod exopod; dte = distal part of telson; "fl" = flagellum; pd = peduncle element; pen = proximal uropod endopod; pex = proximal uropod exopod; pl 1-6=pleomeres; pte $=$ proximal region of telson; te $=$ telson; $u r=$ uropod.

Fig. 4. Paracancrinos libanensis (Garassino and Schweigert, 2006), early instar MNHN.F.48952, continued. A. Red-cyan stereo-anaglyph (please use red-cyan glasses to view, red left, cyan right) of the ventral region of the cephalothorax. B. Colour-marked version of A. Abbreviations: an = antenna; at = antennula; es? = possible eye stalks; le = lateral extension; mp2? = possible maxilliped $2 ; \mathrm{mp} 3=$ maxilliped $3 ; \mathrm{st}=$ thoracic sternum; tp4-8 = thoracopods. 
Fig. 5. Paracancrinos libanensis (Garassino and Schweigert, 2006), early instar MNHN.F.A48973. A. Overview. B. Red-cyan stereo-anaglyph (please use red-cyan glasses to view, red left, cyan right) of the specimen. C. Close up of antennula. D, E: Close-up of antenna. Note short flagellum ("fl"). Arrows mark boundaries between articles. F. Close-up of tail fan. Abbreviations: an = antenna; at $=$ antennula; $\mathrm{cg}$ = cervical groove; den = distal uropod endopod; $\mathrm{fl}=$ flagellum; le = lateral extension; on = optical notch; pd1-3 = peduncle element; pen = proximal uropod endopod; pex = proximal uropod exopod; pl1-6 = pleomeres; pte = proximal region of telson; rs= rostrum; sh? = possible small shrimp; te $=$ telson; ur $=$ uropod.

Fig. 6. Charbelicaris maronites gen. nov., sp. nov. from the Hadjoula Lagerstätte (Cretaceous, Lebanon). A-C. Holotype MNHN.F.A48955. A. Overview. B. Close-up of antennula and antenna. C. Close-up of tail fan. D-G. Paratype MNHN.F.A48984. D. Overview. E. Close-up of antenna. F. Colour-marked version of E. G. Close-up of tail fan. Abbreviations: 1-15 = former antennal articles; an = antenna; at = antennula; den = distal uropod endopod; dex = distal uropod exopod; dte = distal part of telson; $\mathrm{fl}=$ flagellum; le $=$ lateral extension; on = optical notch; pen = proximal uropod endopod; pex = proximal uropod exopod; pl1-6 = pleomeres; pte $=$ proximal region of telson .

Fig. 7. Phylogeny and evolution of Achelata. A. Phylogram of Achelata. B. Evolutionary scenario of the antenna of the early lineage towards modern slipper lobsters (antennae depicted without peduncle element 1). In Palinurida the antenna is relatively slender, elongate and composed of numerous elements. In Scyllarida sensu lato the distal part of the antenna is petaloid and composed of about 20 elements, which are fully articulated. In Scyllarida sensu stricto the distal region is petaloid and composed of about 15 elements; only the distal elements are fully articulated. The peduncle elements are moderately laterally extended; optical notches are present. In Verscyllarida the petaloid region is fully conjoined, the lateral extension of the third peduncle article is leafshaped. In Neoscyllarida the petaloid region is asymmetrical and the lateral extension is more pronounced. 
3.

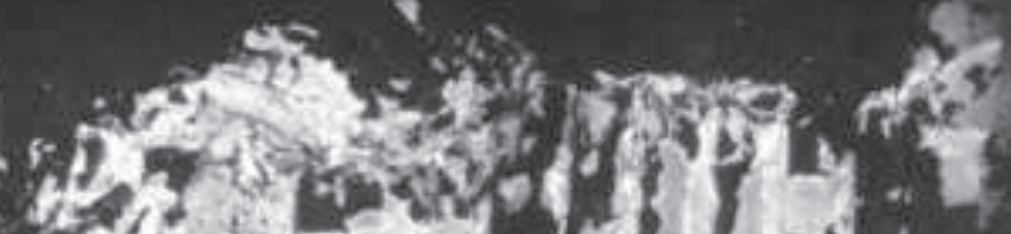

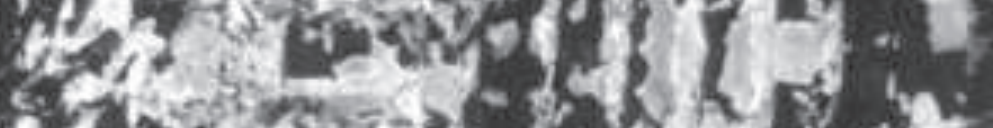

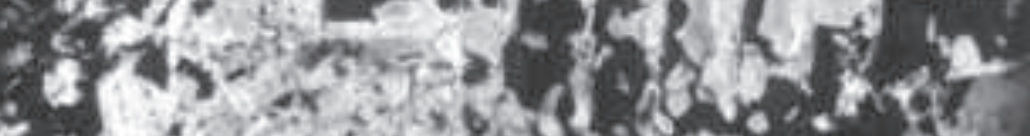

$\operatorname{lis}_{5}$

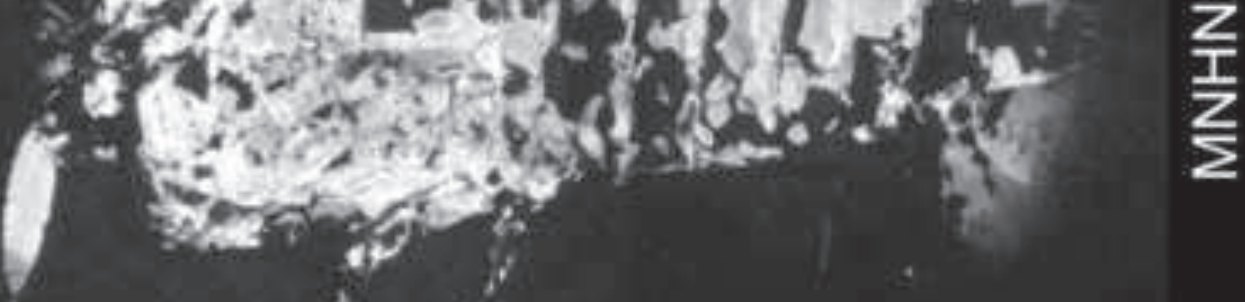




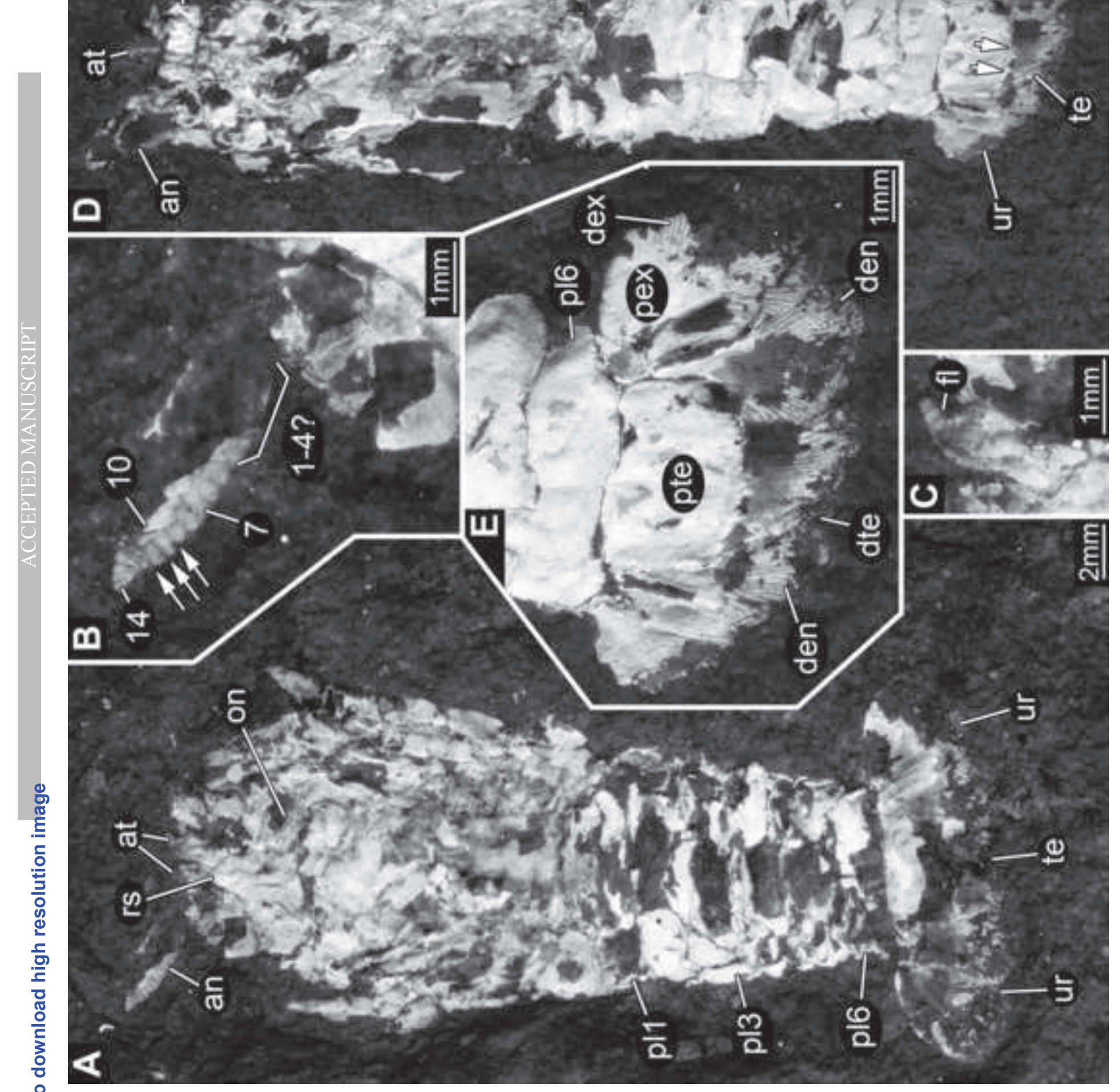




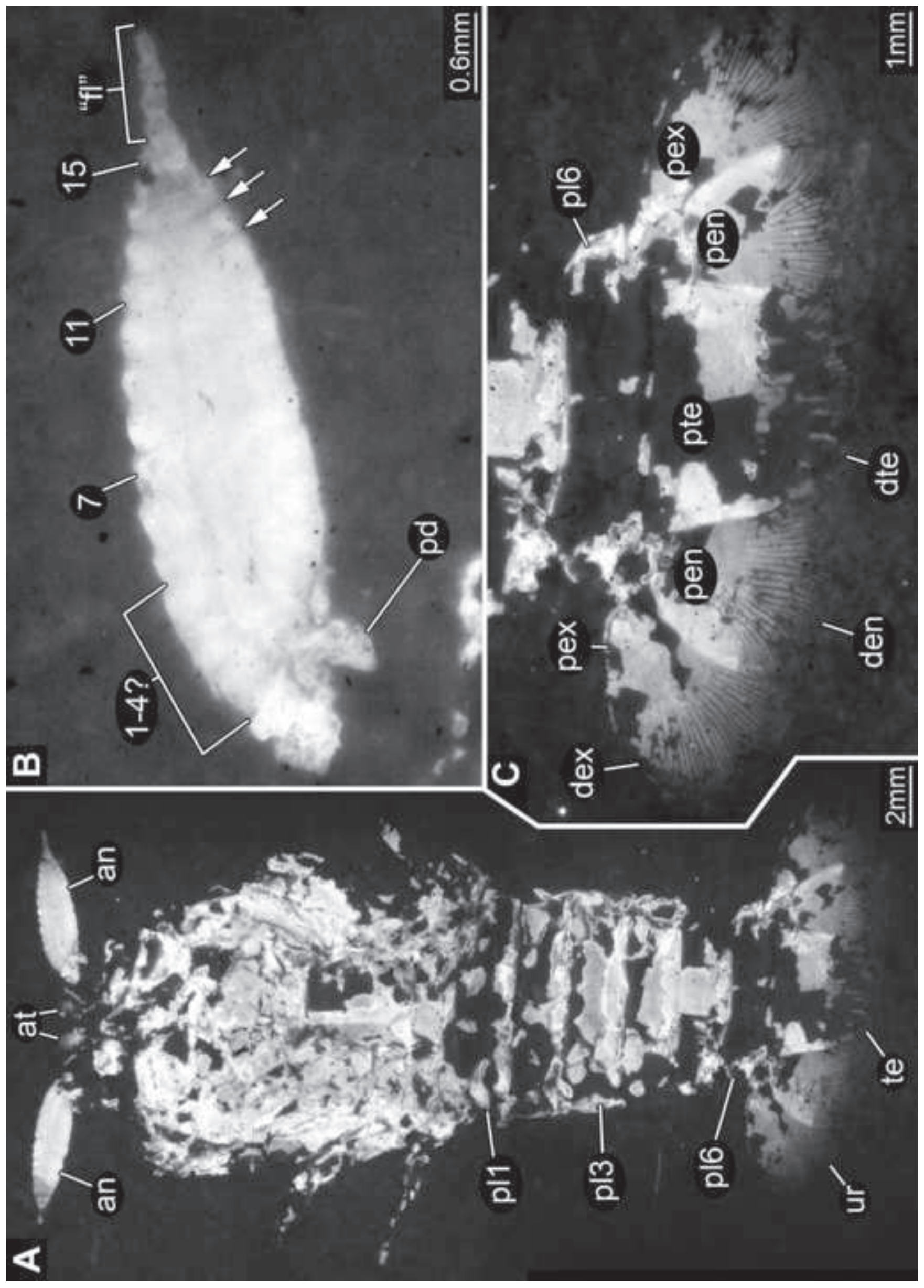



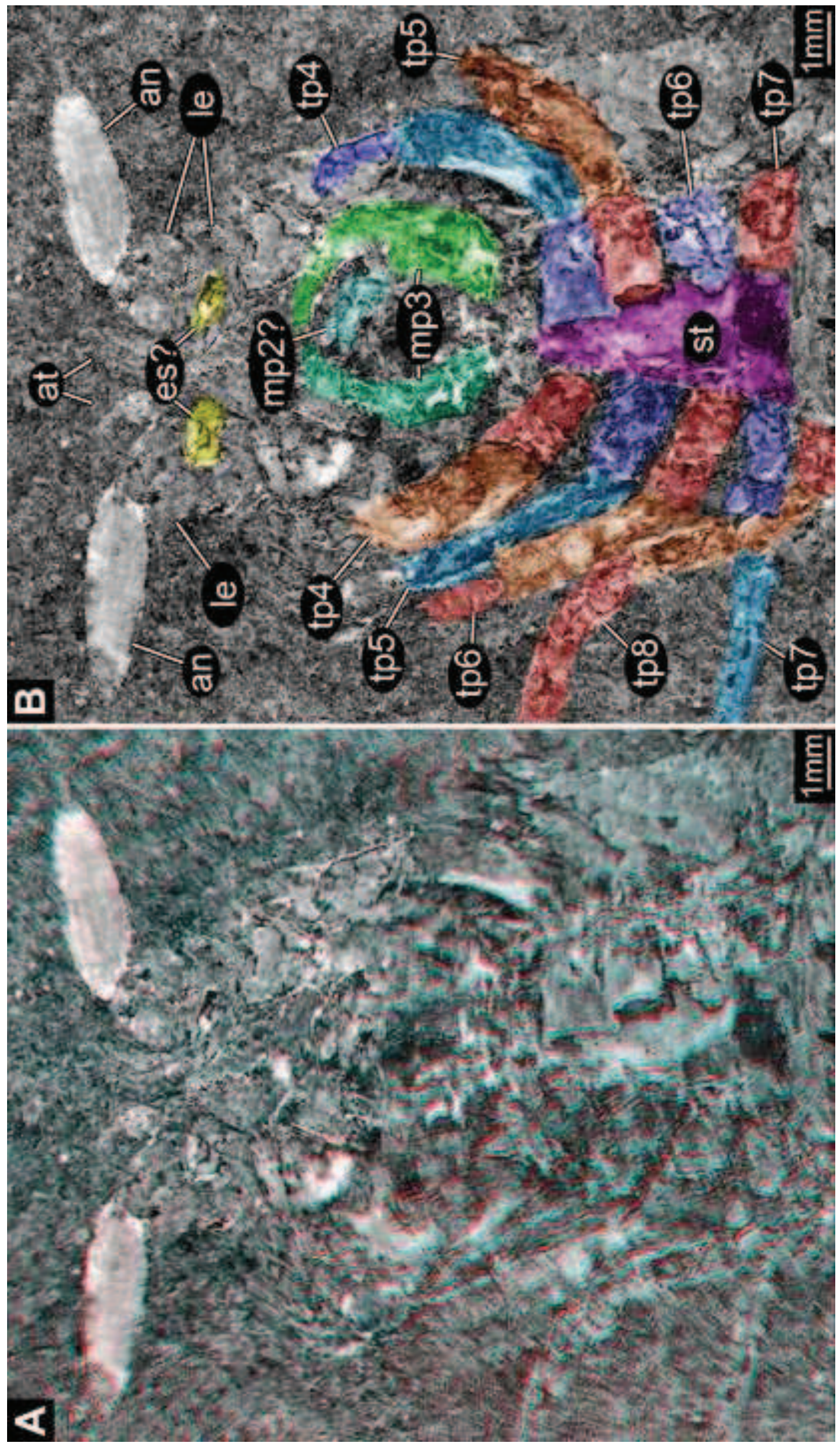


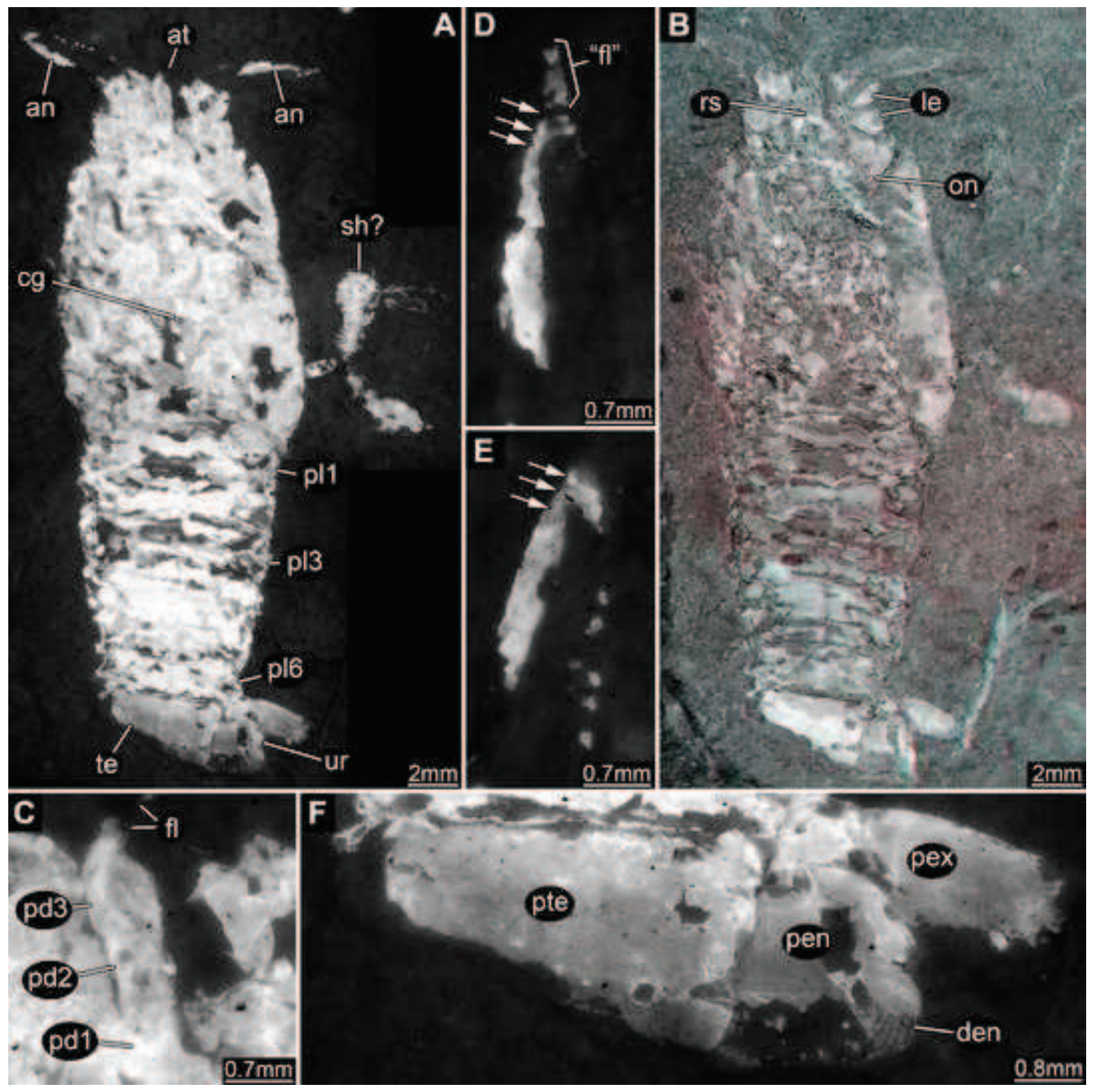




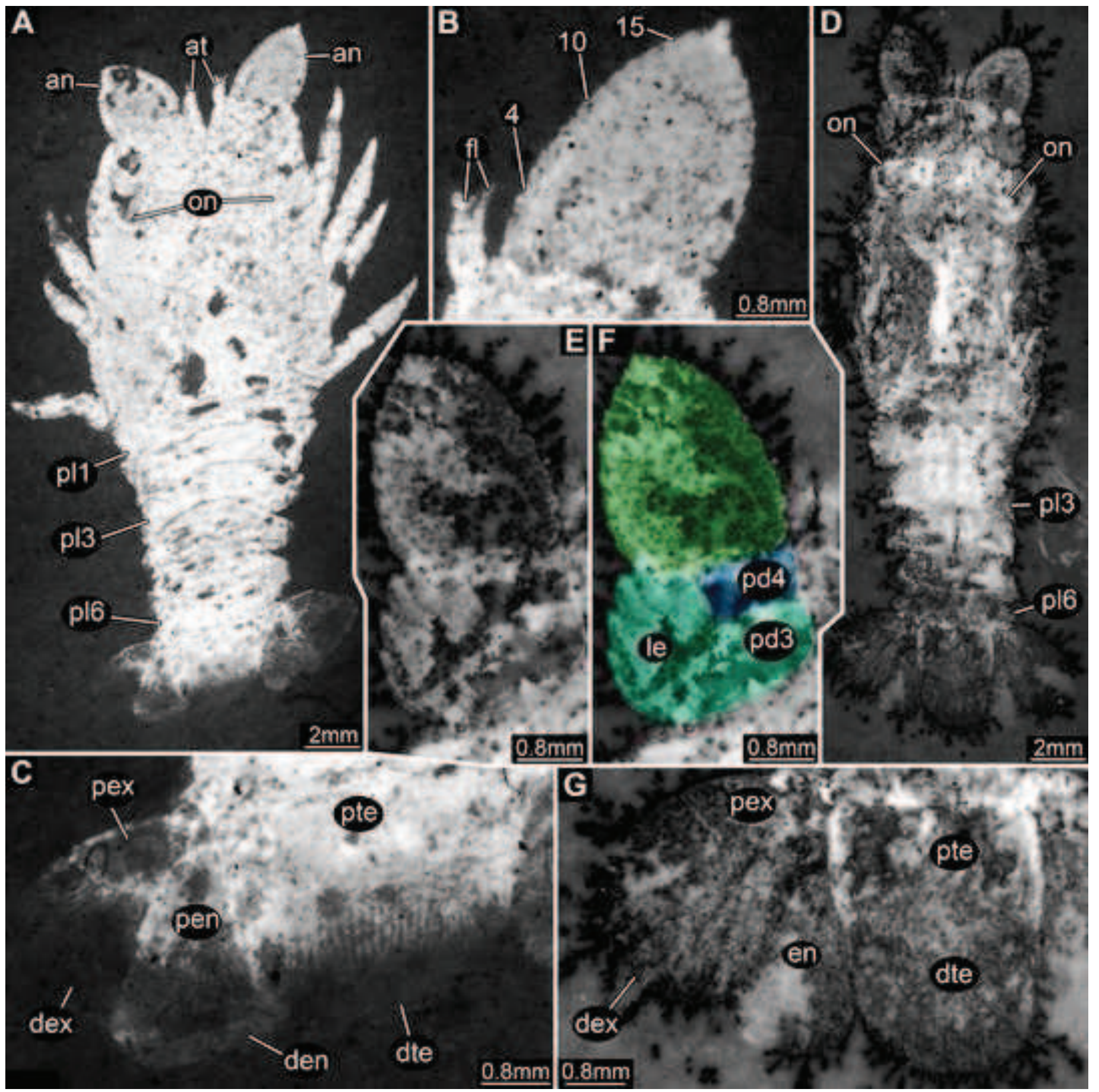




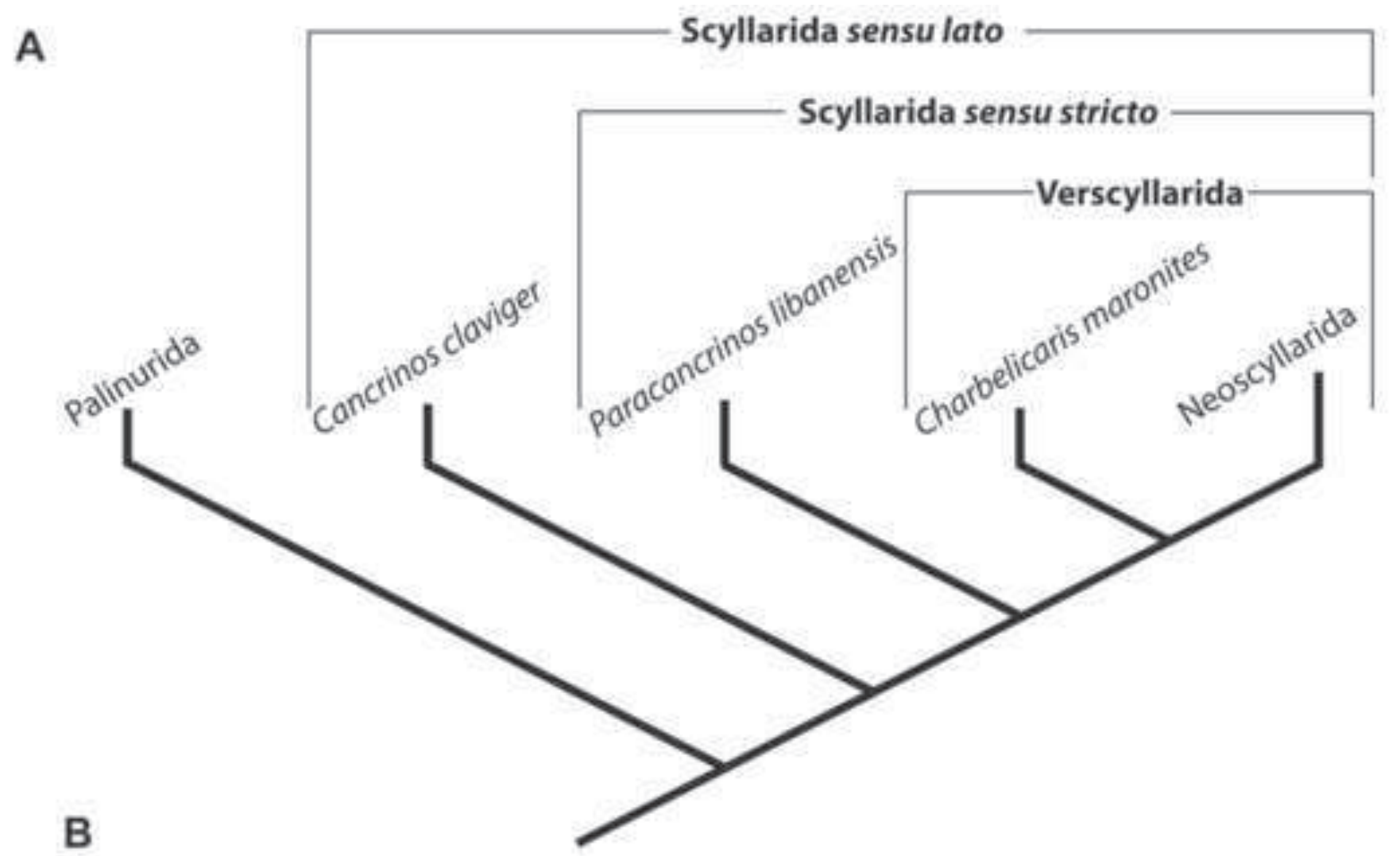

\section{Palinurida}

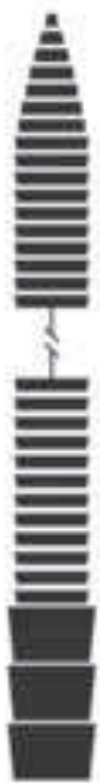

Scyllarida sensu lato

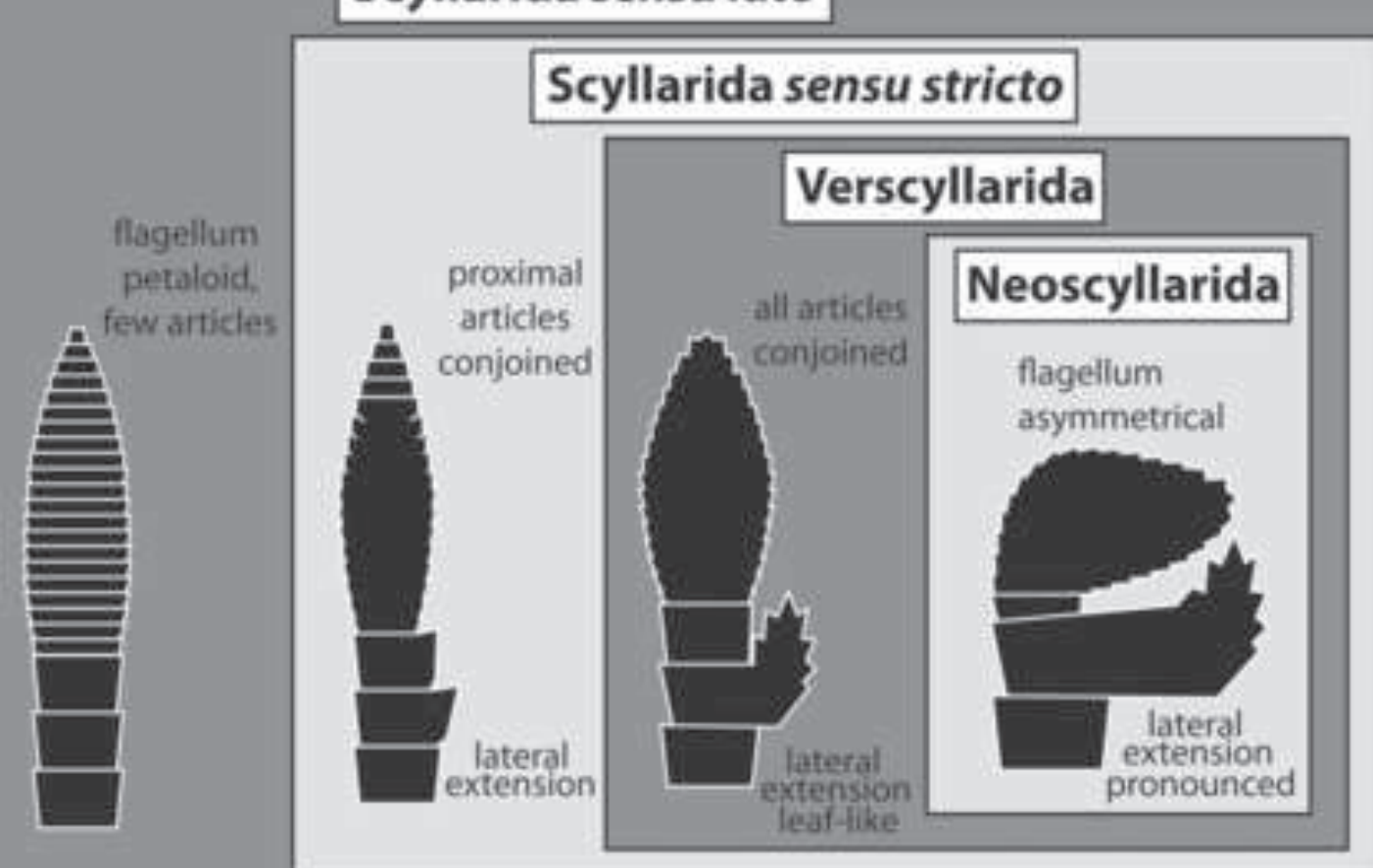




\section{Highlights}

- We describe new fossil, 90 million years old slipper lobsters (in the wide sense).

- These new fossils narrow the gap in the character evolution of slipper lobsters.

- Specifically the evolution of the special antenna can be reconstructed step by step. 
Post-ocular segment 1

Post-ocular segment 2

Post-ocular segment 3

Post-ocular segment 4

Post-ocular segment 5

Post-ocular segment 6

Post-ocular segment 7

Post-ocular segment 8

Post-ocular segment 9

Post-ocular segment 10

Post-ocular segment 11

Post-ocular segment 12

Post-ocular segment 13 Carapace shape in dorsal view

Anterior rim

Latero-anteriorly

Lateral rim of carapace

Cervical groove

Posterior rim

Post-ocular segment 14 Tergite length

Tergite width

Tergopleura

Post-ocular segment 15

Tergite length

Tergite width

Tergopleura

Tergopleura shape

Posterior rim

Tergopleura surface

Post-ocular segment 16

Tergite length

Tergite width

Tergopleura

Tergopleura shape

Postero-lateral rim Tergopleura surface

Post-ocular segment 17 Tergite length

Tergite width

Tergopleura

Tergopleura shape

Lateral rim

Post-ocular segment 18 Tergite length

Tergite width

Tergopleura

Tergopleura shape

Lateral rim

Tergopleura surface

Post-ocular segment 19

Tergite length

Tergite width

Tergopleura

Tergopleura shape Telson (presumably) into 20 segments and the non-somitic telson.

dorsally contributing to the cephalothoracic shield (carapace).

dorsally contributing to the cephalothoracic shield (carapace).

dorsally contributing to the cephalothoracic shield (carapace).

dorsally contributing to the cephalothoracic shield (carapace).

dorsally contributing to the cephalothoracic shield (carapace).

dorsally contributing to the cephalothoracic shield (carapace).

dorsally contributing to the cephalothoracic shield (carapace).

dorsally contributing to the cephalothoracic shield (carapace).

dorsally contributing to the cephalothoracic shield (carapace).

dorsally contributing to the cephalothoracic shield (carapace).

dorsally contributing to the cephalothoracic shield (carapace).

dorsally contributing to the cephalothoracic shield (carapace).

dorsally contributing to the cephalothoracic shield (carapace).

dorsally contributing to the cephalothoracic shield (carapace). sub-rectangular,

about $1.1 \mathrm{x}$ as long as wide.

about as long as wide (slight variations due to preservation). drawn out into short rostrum.

without apparent rostrum.

with pronounced optical notches

strongly serrate.

weakly developed, positioned half the way along the anteriorposterior axis.

difficult to assess, due to preservation.

strengthened by carina.

(pleomere 1) dorsally with a separate sclerite, the tergite.

about $0.25 x$ as long as the carapace.

about as wide as the carapace.

details unknown due to preservation.

(pleomere 2) dorsally with a separate sclerite, the tergite. about $0.25 x$ as long as the carapace.

about as wide as preceding tergite.

about $0.4 x$ the width of the axial region, on one side.

about $0.3 x$ the width of the axial region, on one side.

anterior rim gently rounded, merging into lateral rim. Posterior rim straight. Lateral and posterior rim meeting in a distinct point, which might be slightly drawn out into a spine.

roughly triangular.

apparently denticulate.

with apparent facet.

(pleomere 3 ) dorsally with a separate sclerite, the tergite.

about $0.25 x$ as long as the carapace.

slightly narrower than preceding tergite (about $0.9 x$ ).

about $0.4 x$ the width of the axial region, on one side.

about $0.3 x$ the width of the axial region, on one side.

resembling that of preceding segment, yet anterior rim less

rounded, more straight. Posterior rim slightly curving

anteriorly.

roughly triangular, with denticulate margin.

roughly triangular, with

with apparent facet.

(pleomere 4 ) dorsally with a separate sclerite, the tergite. about $0.25 x$ as long as the carapace.

slightly narrower than preceding tergite (about $0.85 x$ ).

about $0.4 x$ the width of the axial region, on one side.

about $0.3 x$ the width of the axial region, on one side.

differing from preceding segment, anterior rim straighter,

posterior rim more rounded; appearing lobe-like.

roughly triangular, with denticulate margin.

apparently denticulate.

(pleomere 5) dorsally with a separate sclerite, the tergite. about $0.25 x$ as long as the carapace.

slightly narrower than preceding tergite (about $0.9 x$ ).

about $0.4 x$ the width of the axial region, on one side.

resembling that of preceding segment, lobe-like.

roughly triangular, with denticulate margin.

apparently denticulate.

with apparent facet.

(pleomere 6) dorsally with a separate sclerite, the tergite. about $0.25 x$ as long as the carapace.

slightly narrower than preceding tergite (about $0.9 x$ ).

details unknown due to preservation.

about $0.4 x$ the width of the axial region, on one side.

roughly triangular, with denticulate margin.

well-developed. 
Ventral details of ocular segment.

Ventral details of postocular segment 1 .

Ventral details of postocular segment 2 .

Ventral details of postocular segment 3 . Ventral details of postocular segment 4. Ventral details of postocular segment 5 . Ventral details of postocular segment 6 . Ventral details of postocular segment 7 .

Ventral details of postocular segment 8 .

Ventral details of postocular segment 9 .

Ventral details of postocular segment 10 .

App

Telson subdivided into

Hard part of telson

Posterior edge of hard part

Surface of telson

Soft part of telson

Possible eye stalks

Appendage of post-ocular segment 1 Peduncle

Peduncle element 1

Peduncle element 2

Peduncle element 3

Flagella

Appendage of post-ocular segment 2 Peduncle with

Peduncle element 1

Peduncle element 2

Peduncle element 3

Leaf-like structure

Peduncle element 4

Peduncle element 5

Distal flagellum with

Proximal articles (1-9)

Further distal articles (10-12)

Further distal articles (13-15)

Distal articles (16-20)

Shape of distal flagellum

about as long as wide (appears to vary due to preservation). an anterior well sclerotised part and a softer posterior part. about $0.5 x$ of the entire length.

straight, with two denticles.

concave.

without apparent carinae. axis, branching distally.

short and stout.

(antennula) with proximal peduncle and distal flagella.

with three elements.

details unknown due to preservation.

details unknown due to preservation.

about $1.7 x$ as long as wide (diameter).

slightly wider than preceding element, about as long as wide. appear relatively short, with few flagellimeres.

(antenna) with proximal peduncle and distal flagellum. presumably 5 elements

presumably medially fused.

details unknown due to preservation.

robust, shorter than wide. Slightly drawn out laterally.

robust, shorter than wide. Drawn out laterally into leaf-like structure.

with 1 median, 1 distal and 3 lateral serrations.

robust, shorter than wide. Slightly drawn out laterally.

robust, shorter than wide.

presumably conjoined with further distal (flagellar) articles. about 20 articles in early instar; about 15 articles in later instar. Articles indicated by joints and/or indentations. about 17 articles. Articles indicated by indentations.

fully conjoined, indicated by indentations.

fully conjoined, indicated

fully conjoined (at least in some instars), indicated by indentations.

articulated

fully conjoined, indicated by indentations.

flagellate in early instar; lacking in later instar.

petaloid in shape,

about $2.8 x$ as long as wide

about $1.5 x$ as long as wide

Appendage of post-ocular segment 3 (mandible) unknown due to preservation.

Appendage of post-ocular segment 4 (maxillula) unknown due to preservation.

Appendage of post-ocular segment 5 (maxilla) unknown due to preservation.

Appendage of post-ocular segment 6 (maxilliped 1) unknown due to preservation.

Appendage of post-ocular segment 7 (maxilliped 2) only partly known due to preservation. (maxilliped 2) unknown due to preservation.

Appendage of post-ocular segment 8 (maxilliped 3) only partly known due to preservation, generally leg-like, but significantly smaller than succeeding appendages.

(maxilliped 3) unknown due to preservation.

(thoracopod 4) subdivided into a least four elements, exact

Appendage of post-ocular segment 9 arrangement unclear due to preservation.

Element 1

(coxa? coxa+basis?) about $1.35 x$ as long as wide (diameter)

Element 2

long as preceding element, about the same

$2.5-3 x$ as long as wide.

Element 3

about as long as element 1 , but narrower.

slightly shorter than preceding element, but same diameter. about as long as element 1 , but narrower, distally tapering with a rounded tip.

shorter than preceding segment, narrower, distally tapering.

conjoined with succeeding sternite to form thoracic sternum. (thoracopod 5) subdivided into a least four elements, exact

Sternite

\section{Appendage of post-ocular segment 10 arrangement unclear due to preservation.}

Element 1 (second proximal element?) exact length unclear; proximal region covered by carapace.

about $2 \mathrm{x}$ as long as preceding element, about the same

Element 2

diameter.

2.5-3x as long as wide.

Element 3

about as long as element 1 , but narrower.

slightly shorter than preceding element, but same diameter. about as long as element 1 , but narrower, distally tapering

Element 4 with a rounded tip.

shorter than preceding segment, narrower, distally tapering. conjoined with preceding succeeding sternite to form thoracic sternum.

(thoracopod 6) subdivided into a least four elements, exact

Appendage of post-ocular segment 11 arrangement unclear due to preservation. with about 25 "stiffeners" oriented in the anterior-posterior
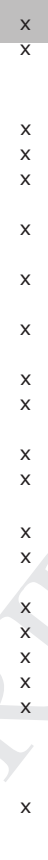
(coxa? coxa+basis?) about 1.35x as long as wide (diameter) (second proximal element?) exact length unclear; proximal region covered by carapace.

about $2 x$ as long as preceding element, about the same diameter.

Element 2

2.5-3x as long as wide.

Element 3 about as long as element 1, but narrower.

slightly shorter than preceding element, but same diameter.

Element 4 about as long as element 1 , but narrower, distally tapering with a rounded tip.

shorter than preceding segment, narrower, distally tapering. conjoined with preceding succeeding sternite to form thoracic

Ventral details of postocular segment 12 .

Sternite

sternum.

Appendage of post-ocular segment 12 arrangement unclear due to preservation.

Element 1

(coxa? coxa+basis?) about $1.35 \mathrm{x}$ as long as wide (diameter) (second proximal element?) exact length unclear; proximal region covered by carapace.

about $2 x$ as long as preceding element, about the same

diameter.

Element 2

2.5-3x as long as wide.

Element 3

about as long as element 1 , but narrower.

slightly shorter than preceding element, but same diameter. about as long as element 1 , but narrower, distally tapering

Element 4 with a rounded tip.

shorter than preceding segment, narrower, distally tapering.

Sternite

conjoined with preceding sternite to form thoracic sternum. triangular in shape. Tip of triangle oriented anteriorly. Height of triangle twice as long as the base.

(thoracopod 8) subdivided into a least four elements, exact

Thoracic sternum

ocular segment 13.

Ventral details of postocular segment 14 Ventral details of postocular segment 15 Ventral details of postocular segment 16. Ventral details of postocular segment 17 . Ventral details of postocular segment 18 . Ventral details of postocular segment 19.

Appendage of post-ocular segment 13 arrangement unclear due to preservation.

(coxa? coxa+basis?) about as long as wide (diameter)

Element 1

Appendage of post-ocular segment 14 (pleopod 1) unknown due to preservation.

Appendage of post-ocular segment 15 (pleopod 2) unknown due to preservation.

Appendage of post-ocular segment 16 (pleopod 3) unknown due to preservation.

Appendage of post-ocular segment 17 (pleopod 4) unknown due to preservation.

Appendage of post-ocular segment 18 (pleopod 5) unknown due to preservation.

Appendage of post-ocular segment 19 (uropod) with basipod, endopod and exopod. Basipod small, rectangular.

subdivided into proximal well sclerotised part and distal soft

Endopod

Proximal sclerotised part

Distal soft part

sub-triangular in dorsal view.

sub-rectangular, distally rounded.

about 20 "stiffeners" oriented in the anterior-posterior axis.

"Stiffeners" branching distally into more than 60 "stiffeners" at

With

Distal margin

Exopod

the distal margin.

smooth.

subdivided into proximal well sclerotised part and distal soft part.

Proximal sclerotised part sub-triangular in dorsal view.

Distal soft part sub-rectangular, distally rounded.

about 20 "stiffeners" oriented in the anterior-posterior axis.

With

Distal margin

"Stiffeners" branching distally into more than 60 "stiffeners" at

the distal margin.

Surface of exopod

smooth.

with carina running along anterior-posterior axis.

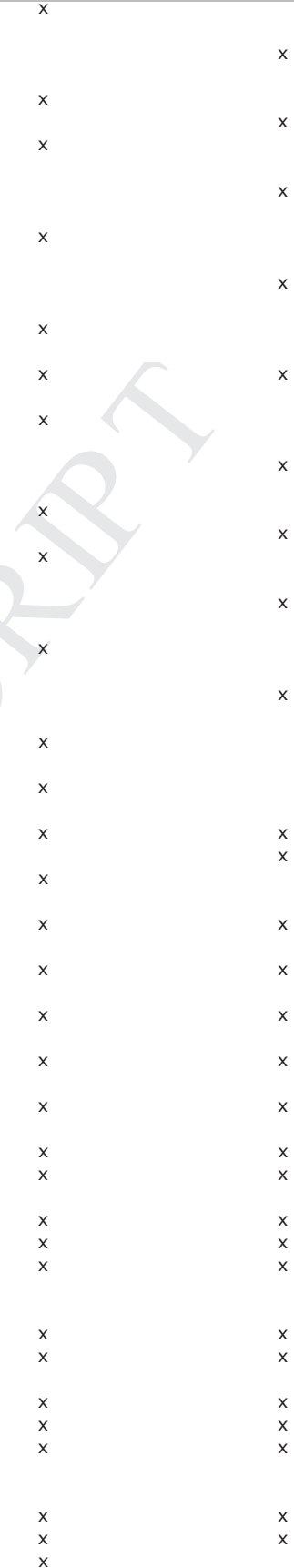

